\title{
Cost of controlling Rhipicephalus microplus in dairy cattle through different methods
}

\section{Custo do controle do Rhipicephalus microplus em bovinos leiteiros considerando diferentes métodos}

\author{
Fábio Henrique Vicente ${ }^{1}$; Marcos Aurélio Lopes ${ }^{2 *}$; Francisco Helton Sá de Lima ${ }^{3}$; \\ Fábio Raphael Pascoti Brunh ${ }^{4}$; Letícia Nogueira Resende ${ }^{5}$; Thiago Zulli Zanardo \\ Resende $^{6}$; Marcelo Simão da Rosa ${ }^{3}$
}

\begin{abstract}
Highlights:
Pour-on was the lowest-cost method.

For calves, the cypermethrin was the lowest cost chemical base;

For heifers and cows, the deltamethrin was the lowest cost chemical base.

The scale of production helped to reduce fixed costs and optimize labor costs.
\end{abstract}

\begin{abstract}
This study examines the cost of applying ixodicides by using three methods (subcutaneous injection, pour-on and spraying), in different animal categories, to generate information that can help in the choice of the method. The research was carried out between May and September 2017, in the dairy cattle section of the Federal Institute of Education, Science and Technology of the South of Minas Gerais - IFSULDEMINAS - Muzambinho campus, state of Minas Gerais, Brazil. All operational expenses related to the application of the ixodicides were recorded. Data were collected by three people: two to time the application of the product and one to record the measured data. Twenty-seven Holstein cattle infested with Rhipicephalus microplus were used, consisting of 12 calves, six heifers and nine adult cows. A simulation was carried out with 50 and 100 animals to check the effect of the production scale on the cost of applying the ixodicides. Application times (animal transport, product dosing and application itself) for the calves, heifers and cow categories were shorter in the injection and pour-on methods, which did not differ from each other in any of the three studied categories. The time spent per animal on the washing of personal protective equipment and washing of sprayer reduced as the number of animals increased, because these procedures are performed only once regardless of the number of animals. The pour-on method was the least expensive. Production scale was found to be an important factor for diluting fixed costs and optimizing labor.
\end{abstract}

Key words: Animal category. Acaricides. Economic viability. Production scale.

\footnotetext{
${ }^{1}$ Discente de Mestrado, Universidade Federal de Lavras, UFLA, Lavras, MG, Brasil. E-mail: fabiohenriquevicente07@hotmail. com

2 Prof. Titular, Departamento de Medicina Veterinária, UFLA, Lavras, MG, Brasil. E-mail: malopes@ufla.br

3 Profs., Instituto Federal de Educação, Ciência e Tecnologia do Sul de Minas Gerais, IFSULDEMINAS, Campus Muzambinho, Muzambinho,MG, Brasil. E-mail: francisco.lima@muz.ifsuldeminas.edu.br; marcelo.rosa@muz.ifsuldeminas.edu.br

4 Prof., Departamento de Veterinária Preventiva, Universidade Federal de Pelotas, UFPel, Pelotas, RS, Brasil. E-mail: fabio_rpb@ yahoo.com.br

5 Discente do Curso de Graduação em Medicina Veterinária, IFSULDEMINAS, Campus Muzambinho, Muzambinho, MG, Brasil. E-mail: leticiaresende42@gmail.com

6 Discente, Curso Técnico em Agropecuária, IFSUldeMINAS, Campus Muzambinho, Muzambinho, MG, Brasil. E-mail: thiagozzanardo@gmail.com

* Author for correspondence
} 


\section{Resumo}

Objetivou-se avaliar o custo da aplicação de carrapaticida utilizando-se três métodos (injetável via subcutânea, pour-on e pulverização), em diferentes categorias animais, com o intuito de fornecer informações que auxiliem na decisão da escolha de um método. A pesquisa foi realizada entre maio a setembro de 2017, no setor de bovinocultura de leite do Instituto Federal de Educação, Ciência e Tecnologia do Sul de Minas Gerais - IFSULDEMINAS - Campus Muzambinho, Minas Gerais. Foram levantadas todas as despesas operacionais referentes à aplicação de carrapaticida. A coleta dos dados foi realizada por três pessoas: duas para cronometrar o tempo de aplicação do produto e uma para anotar os dados aferidos. Foram utilizados 27 animais da raça Holandesa parasitadas por Rhipicephalus microplus, sendo 12 bezerras, seis novilhas e nove vacas adultas. Foi realizada uma simulação com 50 e 100 animais, visando verificar o efeito da escala de produção no custo da aplicação de carrapaticidas. Os tempos para as aplicações dos carrapaticidas (condução do animal, dosagem do produto e aplicação) das categorias de bezerras, novilhas e vacas foram menores nos métodos injetável e pour-on, que não diferiram entre si, em nenhuma das três categorias estudadas. Os tempos gastos por animal relacionados às lavagens do EPI e do pulverizador reduziram à medida que a quantidade de animais aumentou, devido ao fato desses procedimentos serem feitos somente uma vez independentemente da quantidade de animais. O método pour-on foi o de menor custo. Constatou-se que a escala de produção é um fator importante para diluição dos custos fixos e otimização da mão de obra.

Palavras-chave: Acaricidas. Categoria animal. Escala de produção. Viabilidade econômica.

\section{Introduction}

Ticks constitute one of the most important ectoparasitic infections in cattle farming. It is estimated that $80 \%$ of the world herd is infested with ticks (Bowman \& Nuttall, 2008). The state of Minas Gerais is a milk production hub in Brazil that suffers the consequences of the high prevalence of Rhipicephalus microplus.

Rocha et al. (2006) reported that farmers are aware that ticks cause damage, but there is a lack of understanding about their biology and the problems arising from incorrect application of ixodicides (i.e., tick killers). Farm management prioritizes production, and farmers are not interested in modifying the management to favor the control of this parasitic infection (Santos, Furlong, \& Daemon, 2000; George, Pound, \& Davey, 2004).

Due to the great importance of the tick $R$. microplus, several researchers have studied different aspects of this pest, e.g., its impact on milk production (Melo, Passos, Facury, Saturnino, \& Ribeiro, 2001; Bowman \& Nuttall, 2008); strategic control (Camillo, Vogel, Sangioni, Candore, \&
Ferrari, 2009); resistance to acaricides (Sutherst \& Comins, 1979; Silva, Neves, \& Linhares, 2000; Gauss \& Furlong, 2002; Spagnol, Paranhos, \& Albuquerque, 2010); and factors associated with its prevalence in the herd (Kasai, Labruna, Pires, Louvandini, Abdalla, \& Gennari, 2000; Santos et al., 2000; Piper et al. 2010). However, no research results regarding the cost for the application of ixodicides have been found. In view of the importance of this topic, the present study was developed to examine the cost of applying ixodicides using three different methods, aiming to generate information that helps technicians and farmers choose a method.

\section{Material and Methods}

The study was carried out from May to September 2017, in the dairy cattle section of the Federal Institute of Education, Science and Technology of the South of Minas - IFSULDEMINAS Muzambinho campus, state of Minas Gerais, Brazil.

All operational expenses related to the application of ixodicides were analyzed using three different methods: subcutaneous injection, pour- 
on and spraying with a backpack sprayer. For the budgeting, we quantified the variable costs, which refer to labor and disposable gloves; and fixed costs, which refer to the depreciation of the equipment used in the application of the ixodicide, considering that the equipment will be used in several production cycles. Depreciation was calculated by the straightline method (Hoffmann, Serrano, Neves, Thame, \& Engler, 1981).

Data collection was carried out by a team of three people: two to time the product application and one to record the obtained data. All repetitions were performed by the same people. Twenty-seven Holstein animals were used (12 calves, six heifers and nine adult cows), which were identified with plastic earrings. The same animals were used for all three methods.

The injectable subcutaneous applications were performed in the stalls of the dairy cattle section. Firstly, the processes of putting on the disposable gloves and filling the automatic gun syringe was timed. Three people were needed for handling the animals: one to lead them to the restraining chute, one to open the chute and one to secure the animals to the chute and apply the product. The time for conducting the cattle to the individual restraining chute began when the chute was opened and ended when the animal was completely restrained. The stopwatches were started again when the applicator was ready to apply the product (in the neck side region) and stopped once the product was applied. The time to release the animal from the restraining chute was also measured.

Applications by the pour-on method also occurred in the dairy cattle sector. First, the time to put on the disposable gloves was measured. Two people were needed for handling the animals: one to lead them to the restraining chute and one to apply the product. The time spent on walking the cattle to the restraining chute began when the site was opened and ended when the animals were inside the chute. Five animals were conducted at a time. The stopwatches were started to measure the amount of ixodicides, using the measuring cup inside the very product bottle, and stopped after dosing. The stopwatch was started again when the applicator was ready to apply (in the dorsolumbar region) and stopped once the product was applied. The time to release the animals from the restraining chute was also measured.

Finally, for the spray applications, the processes of wearing personal protective equipment (PPE) and preparing the ixodicide solution were firstly timed. Two people were required for handling the animals: one for leading them and for the physical restraining procedure and one for applying the product. The timing began with the restraining of the animal with a halter and tying them on a pole. In addition, a hopple was made to avoid accidents with kicks, aiming to ensure the safety of the team. After the procedure was finished, the stopwatches were stopped. Subsequently, the procedures of product application, release of the animals and washing of sprayer and PPE were timed.

Throughout the procedure, the welfare principles of workers and animals were met. All data, namely, animal number, route of application and time spent on application, were recorded in an Excel spreadsheet developed specifically for this purpose.

The inputs required for the application of the ixodicide in the different methods, as well as their respective prices, are listed in Table 1. Labor expenses were obtained by multiplying the time spent on the procedure for the application of the ixodicide, in each animal, by the remuneration (in Brazilian Reais, R\$) for the employee's labor time $(\mathrm{R} \$ 0.002 / \mathrm{s})$. This number was obtained by converting the hourly pay $(\mathrm{R} \$ 6.25)$ into the remuneration received per second.

Data referring to the incurred expenses were recorded in a field book and in an Excel spreadsheet developed specifically for this purpose.

A simulation was carried out with 50 and 100 animals to analyze the effect of the production scale 
using the different methods, since some procedures (wearing and washing of PPE and washing of sprayer) are performed only once regardless of the number of animals, optimizing the workforce. The simulation was also aimed at determining the effect of the dilution of the depreciation of the equipment used by the increase in number of animals, following the methodology used by Lopes and Santos (2007).

Table 1

Inputs required for the application of ixodicides using three different methods

\begin{tabular}{|c|c|c|c|c|c|}
\hline \multicolumn{6}{|c|}{ Application method } \\
\hline Input & Injection & Pour-on & Spraying & Unit & Cost (R\$) \\
\hline \multicolumn{6}{|l|}{ Permanent $^{1}$} \\
\hline Backpack sprayer & & & $\mathrm{X}$ & un & 179.00 \\
\hline $\mathrm{PPE}^{2}$ & & & $\mathrm{X}$ & un & 98.00 \\
\hline Gun syringe & $\mathrm{x}$ & & & un & 150.00 \\
\hline Hose & & & $\mathrm{X}$ & Meters & 1.25 \\
\hline \multicolumn{6}{|l|}{ Consumable } \\
\hline Disposable gloves & $\mathrm{X}$ & $\mathrm{x}$ & & un & 0.18 \\
\hline Labor & $\mathrm{X}$ & $\mathrm{x}$ & $X$ & Hours & 6.25 \\
\hline
\end{tabular}

${ }^{1}$ Inputs subject to depreciation, calculated using the straight-line method; ${ }^{2}$ Brim with neck shade, visor, shirt, apron, pants and gloves.

A description of the data obtained in the field was made based on the calculation of the mean and standard deviation of the times spent (in seconds) on each ixodicide application method and animal category studied. In addition, ANOVA was performed to compare the different cattle categories (calves, heifers and cow), the time spent between the different ixodicide application methods (spray, pour-on and subcutaneous injection), in each animal category (heifer, heifer and cow), followed by a multiple comparison test of Bonferroni's correction, after normal distribution of the data was checked by the Kolmogorov-Smirnov test. The database was constructed and statistical analyses performed using SPSS ${ }^{\circledR} 18.0$ software. A minimum confidence level of $95 \%$ was considered in all statistical analyses $(\mathrm{p}<0.05)$.

\section{Results and Discussion}

The ixodicide application times (animal handling, dosing and application of the product itself) in the calves, heifers and cow categories were shorter when the injection and pour-on methods were applied, which did not differ $(p>0.05)$ in any of the evaluated categories (Table 2). Spraying had a longer application time per animal than the other methods, in the three studied categories (Table 2), as it involves more steps for product application (wearing of PPE, preparation of the ixodicide mixture, individual physical restraining of the animals, longer time for the actual application of the product, washing of the sprayer and removal and washing of PPE) (Table 3). The longer time to wear PPE, in the spray method, is due to the higher number of pieces of protective equipment used (brim with neck shade, visor, shirt, apron, pants and gloves) 
in relation to the other two methods. The product dosing time in the spraying treatment was longer than in the other methods since the entire preparation of the 20-L mixture was considered. However, once the mixture was prepared, it was sufficient for four cows, six heifers, or 14 calves. The times related to the wearing and washing of PPE and washing of the sprayer reduced as the number of animals increased, which is because these procedures are performed only once regardless of the number of animals, thus optimizing the workforce.

Table 2

Time spent applying the ixodicide, in seconds, using three methods in different categories of Holstein animals

\begin{tabular}{ccccc}
\hline Animal category & Method & Mean (seconds) & SD * (seconds) & P-value $^{* *}$ \\
\hline \multirow{3}{*}{ Calves } & Injection & $24.4^{\mathrm{A}}$ & 6.86 & \\
& Spraying & $204.1^{\mathrm{B}}$ & 28.60 & 0.000 \\
& Pour-on & $14.2^{\mathrm{A}}$ & 0.79 & \\
\hline \multirow{3}{*}{ Heifers } & Injection & $41.0^{\mathrm{A}}$ & 41.06 & 0.000 \\
& Spraying & $349.8^{\mathrm{B}}$ & 42.38 & \\
& Pour-on & $19.5^{\mathrm{A}}$ & 0.58 & 0.000 \\
\hline \multirow{3}{*}{ Cow } & Injection & $27.1^{\mathrm{A}}$ & 6.91 & \\
& Spraying & $410.2^{\mathrm{B}}$ & 58.41 & 3.39 \\
\hline
\end{tabular}

Means followed by different letters, in the same column, differ by Bonferroni's test; * SD: standard deviation; ** ANOVA test. 
Table 3

Time spent on procedures for the application of ixodicides using three methods in different categories of Holstein animals, in seconds

\begin{tabular}{|c|c|c|c|c|c|c|c|}
\hline $\begin{array}{l}\text { Animal } \\
\text { category }\end{array}$ & N. of animals & $\begin{array}{l}\text { Application } \\
\text { method }\end{array}$ & $\begin{array}{c}\text { Wearing of PPE* } \\
\text { Seconds }\end{array}$ & $\begin{array}{l}\text { Product } \\
\text { dosing** } \\
\text { Seconds }\end{array}$ & $\begin{array}{l}\text { Washing } \\
\text { of PPE } \\
\text { Seconds }\end{array}$ & $\begin{array}{l}\text { Washing } \\
\text { of sprayer } \\
\text { Seconds }\end{array}$ & $\begin{array}{c}\text { Grand } \\
\text { total } \\
\text { Seconds }\end{array}$ \\
\hline \multirow[t]{9}{*}{ Calves } & 1 & Injection & 19.0 & 5.4 & - & - & 24.4 \\
\hline & 50 & & 0.38 & 270.0 & - & - & 270.38 \\
\hline & 100 & & 0.19 & 540.0 & - & - & 540.19 \\
\hline & 1 & Pour-on & 20.0 & 5.3 & - & - & 25.3 \\
\hline & 50 & & 0.4 & 265.0 & - & - & 265.4 \\
\hline & 100 & & 0.2 & 530.0 & - & - & 530.2 \\
\hline & 1 & Spraying & 179.0 & 119.0 & 196.0 & 80.0 & 574.0 \\
\hline & 50 & & 3.6 & 428.4 & 3.9 & 1.6 & 437.5 \\
\hline & 100 & & 1.8 & 833.0 & 2.0 & 0.8 & 837.6 \\
\hline \multirow[t]{9}{*}{ Heifers } & 1 & Injection & 19.0 & 5.4 & - & - & 24.4 \\
\hline & 50 & & 0.38 & 270.0 & - & - & 270.38 \\
\hline & 100 & & 0.19 & 540.0 & - & - & 540.19 \\
\hline & 1 & Pour-on & 20.0 & 5.3 & - & - & 25.3 \\
\hline & 50 & & 0.4 & 265.0 & - & - & 265.4 \\
\hline & 100 & & 0.2 & 530.0 & - & - & 530.2 \\
\hline & 1 & Spraying & 179.0 & 119.0 & 196.0 & 80.0 & 574.0 \\
\hline & 50 & & 3.6 & 952 & 3.9 & 1.6 & 961.1 \\
\hline & 100 & & 1.8 & 1975.4 & 2.0 & 0.8 & 1980.0 \\
\hline \multirow[t]{9}{*}{ Cow } & 1 & Injection & 19.0 & 5.4 & - & - & 24.4 \\
\hline & 50 & & 0.38 & 270.0 & - & - & 270.38 \\
\hline & 100 & & 0.19 & 540.0 & - & - & 540.19 \\
\hline & 1 & Pour-on & 20.0 & 5.3 & - & - & 25.3 \\
\hline & 50 & & 0.4 & 265.0 & - & - & 265.4 \\
\hline & 100 & & 0.2 & 530.0 & - & - & 530.2 \\
\hline & 1 & Spraying & 179.0 & 119.0 & 196.0 & 80.0 & 574.0 \\
\hline & 50 & & 3.6 & 1487.5 & 3.9 & 1.6 & 1496.6 \\
\hline & 100 & & 1.8 & 2975.0 & 2.0 & 0.8 & 2979.6 \\
\hline
\end{tabular}

*Personal protective equipment; ** In the spraying method, the mixture preparation process was considered. 
The cost of applying the ixodicide to one, 50 and 100 animals of different categories, considering the three methods, is detailed in Table 4. For the calculation of the fixed cost of spraying, the depreciation of sprayer, PPE and hose was considered, whereas in the injection method only the depreciation of the gun syringe was considered. The pour-on method incurred no expenses on depreciation, as this method does not require any depreciating equipment.

For the calves, the ixodicide application costs per animal by the injection, pour-on and spraying methods were $\mathrm{R} \$ 2.970, \mathrm{R} \$ 0.445$ and $\mathrm{R} \$ 6.731$, respectively. This animal category was the least costly, in the three methods, due to the shorter time spent on labor. Lopes, Silva, Demeu, Gomide and Bruhn (2013) took the least time to implement ear tags for identification in this category, as they are smaller animals and easier to contain.

For the heifers, the costs of application by the injection, pour-on and spraying methods per animal were $\mathrm{R} \$ 3.057, \mathrm{R} \$ 0.463$ and $\mathrm{R} \$ 7.231$, respectively. Thehigher cost of application in yearling as compared with calves by the spraying and pour-on methods is because the former are larger, thus requiring more labor time. By the injection method, the application cost was highest for the heifers among all categories due to the difficulty handling them, which extended the time spent on labor. According to Néri, Toledo, Arcaro and Ambrósio (2016), heifers that received tactile stimulation became less aggressive and less resistant to handling. The heifers in this study did not have this type of stimulation, which may have made their behavior more reactive and the time of product application longer.
Lastly, for the cows, the application costs per animal by the injection, pour-on and spray methods were $\mathrm{R} \$ 2.983, \mathrm{R} \$ 0.469$ and $\mathrm{R} \$ 7.441$, respectively. Although they were handled without aversive stimuli, the cost of applying the ixodicide by the injectable and spray methods was higher than in the other categories because cows are the largest of the three studied categories, implying a longer labor time for the application of the product. As stated by Peters, Barbosa, Machado, Machado and Pereira (2010), dairy cows treated with rational management techniques are less reactive and so their management is easier.

As the number of animals increased, the unit values of depreciation and disposable gloves decreased, in all methods (Table 4). This shows the effect of the production scale, which was greatest when the spraying method was adopted, since depreciation has high representativeness in the total operating cost of this method $(80.67 \%$, $75.09 \%$ and $72.97 \%$ for the calves, heifers and cows, respectively). In the opinion of Lopes et al. (2018), the production scale reduces the influence of depreciation on fixed and total costs by optimizing the company's infrastructure up to certain levels. Expenses on wearing PPE, preparing the mixture and washing of sprayer and PPE also decreased as the number of animals increased due to the optimization of workforce, which, according to Lopes et al. (2004), contributes to reducing the effective operating cost.

The higher labor value in the spraying method is explained by the longer time spent on these procedures, which made it the most expensive of all three treatments evaluated in this study. Thus, the pour-on method was the least expensive regardless of the category and number of animals. 


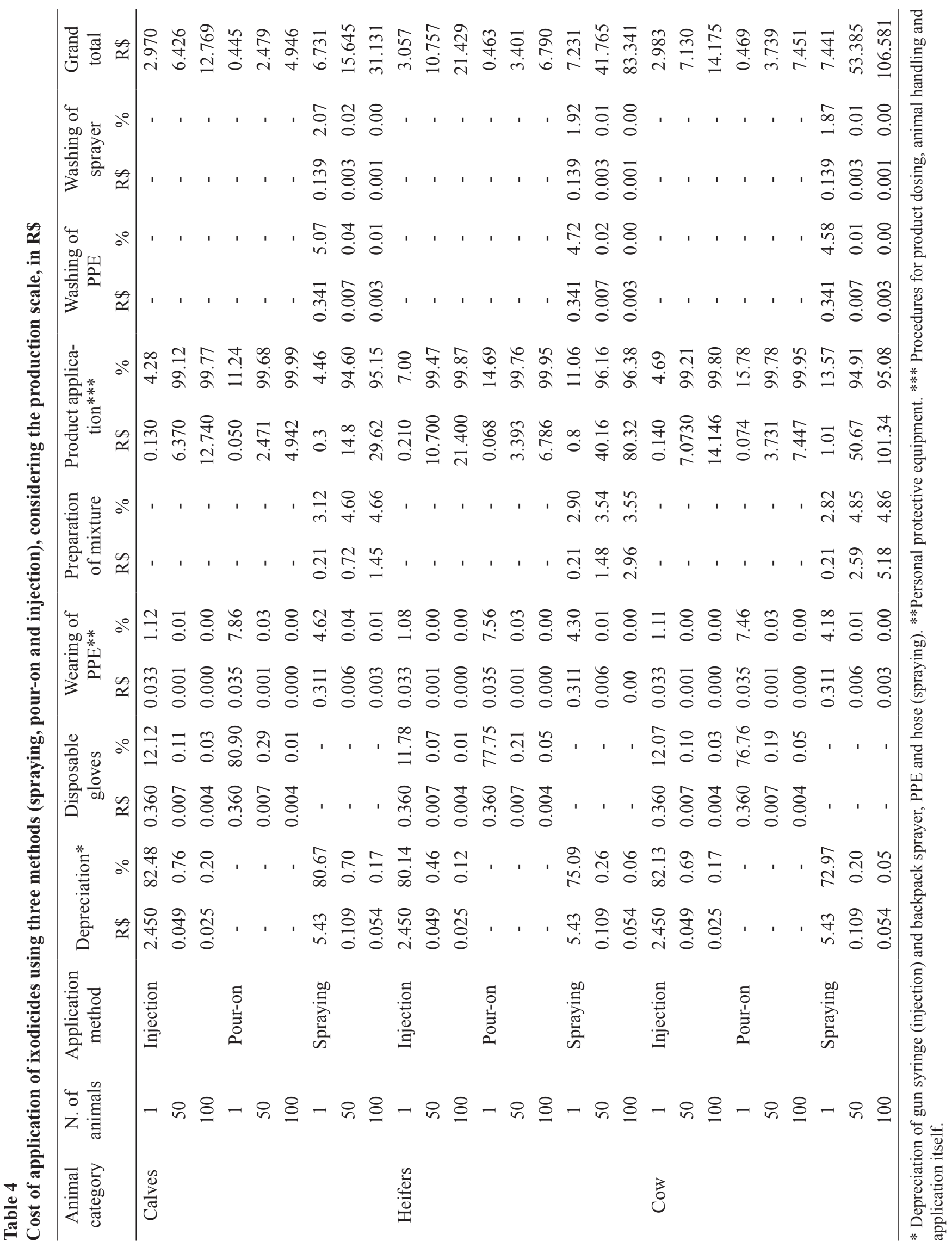


However, for technicians and producers to decide which method to use, they must take into account the efficiency of the method in controlling the tick, the efficiency of the active ingredient of the product used, and the available infrastructure on the farm. In this respect, the cost per administered dose of ixodicide was estimated (in R\$) per method
(Table 5), taking as a reference the active ingredients recommended by Daher, Bertolluci, Lopes, Guimarães and Rocha (2012) based on the in vitro ixodicide resistance test ("biocarrapaticidograma") performed in the region where this research was carried out.

Table 5

Cost, in R\$, per administered dose of the ixodicide considering different active ingredients, using three methods in animal categories of the Holstein breed

\begin{tabular}{|c|c|c|c|c|}
\hline Animal category & $\begin{array}{l}\text { Application } \\
\text { method }\end{array}$ & Active ingredient of the product & $\begin{array}{l}\text { Price per } \mathrm{mL} \\
\quad(\mathrm{R} \$)\end{array}$ & $\begin{array}{l}\text { Cost per administered } \\
\text { dose }(\mathrm{R} \$)^{*}\end{array}$ \\
\hline \multirow[t]{8}{*}{ Calves** } & Injection & Ivermectin & 0.30 & 0.60 \\
\hline & & Cypermethrin + Chlorpyrifos & 0.04 & 0.40 \\
\hline & Pour-on & Cypermethrin & 0.01 & 0.10 \\
\hline & & Fipronil & 0.05 & 0.50 \\
\hline & & Chlorfenvinphos + Dichlorvos & 0.25 & 0.89 \\
\hline & & Dichlorvos + Chlorpyrifos & 0.08 & 0.60 \\
\hline & Spraying & Deltamethrin & 0.05 & 0.15 \\
\hline & & Amitraz & 0.08 & 0.48 \\
\hline \multirow[t]{8}{*}{ Heifers*** } & Injection & Ivermectin & 0.30 & 2.10 \\
\hline & & Cypermethrin + Chlorpyrifos & 0.04 & 1.60 \\
\hline & Pour-on & Cypermethrin & 0.01 & 0.35 \\
\hline & & Fipronil & 0.05 & 1.75 \\
\hline & & Chlorfenvinphos + Dichlorvos & 0.25 & 2.08 \\
\hline & Snroving & Dichlorvos + Chlorpyrifos & 0.08 & 0.80 \\
\hline & spraying & Deltamethrin & 0.05 & 0.20 \\
\hline & & Amitraz & 0.08 & 0.64 \\
\hline \multirow[t]{8}{*}{ Cow**** } & Injection & Ivermectin & 0.30 & 3.60 \\
\hline & & Cypermethrin + Chlorpyrifos & 0.04 & 2.00 \\
\hline & Pour-on & Cypermethrin & 0.01 & 0.60 \\
\hline & & Fipronil & 0.05 & 3.00 \\
\hline & & Chlorfenvinphos + Dichlorvos & 0.25 & 3.12 \\
\hline & Snraving & Dichlorvos + Chlorpyrifos & 0.08 & 1.00 \\
\hline & spraying & Deltamethrin & 0.05 & 0.25 \\
\hline & & Amitraz & 0.08 & 0.80 \\
\hline
\end{tabular}

* Dose according to the product's package insert. ** Considering a live weight of $100 \mathrm{~kg} . * * *$ Considering a live weight of $350 \mathrm{~kg}$. $* * * *$ Considering a live weight of $600 \mathrm{~kg}$. 
In this study, the lowest cost for the application of the ixodicide was obtained with the pour-on method, regardless of the animal category. For the calves, the lowest-cost active ingredient was cypermethrin, which is applied by the pour-on method. For heifers and cows, the least expensive active ingredient was deltamethrin, which is applied via spraying. Considering the sum of the lowest prices of the active ingredients and their respective application methods (Tables 5 and 4, respectively), the total costs for the applications of the ixodicide were $\mathrm{R} \$ 0.545, \mathrm{R} \$ 77.431$ and $\mathrm{R} \$ 7.691$ per animal for calves, heifers and cows, respectively.

\section{Conclusions}

Pour-on was the least costly of the three studied application methods. The production scale was found to be an important factor to reduce the representativeness of fixed costs and optimize the workforce, especially when the spraying method was employed. Cypermethrin was the lowest-cost active ingredient for the application of ixodicides on calves, whereas Deltamethrin was the least costly active ingredient for heifers and cows. However, it is up to the producer and/or technician to define which ixodicide application method is the most suitable to the reality of their farm, considering the advantages and limitations of each one.

\section{Ethics Committee on Animal Experimentation}

The experimental procedures were approved by the Ethics Committee on Animal Experimentation of the Federal University of Lavras (approval no. CETEA 047/14).

\section{Acknowledgments}

Thanks are due to he Federal Institute of Education, Science and Technology of the South of Minas - IF SUL DE MINAS - Muzambinho campus, for the financial support provided for the development of this research.

\section{References}

Bowman, A. S., \& Nuttall, P. A. (2008). Ticks: biology, disease and control. Cambridge: Cambridge University Press.

Camillo, G., Vogel, F. F., Sangioni, L. A., Cadore, G. C., \& Ferrari, R. (2009). Eficiência in vitro de acaricidas sobre carrapatos de bovinos no Estado do Rio Grande do Sul, Brasil. Ciência Rural, 39(2), 490-495. doi: 10.1590/S0103-84782008005000082

Daher, D. O., Bertolluci, A. V., Lopes, E., Guimarães, A. M., \& Rocha, C. M. B. M. (2012). Fatores associados à resistência do Rhipicephalus (Boophilus) microplus (Canestrini, 1887) no sul de Minas Gerais. Revista Verde, 7(1), 102-115.

Gauss, C. L. B., \& Furlong, J. (2002). Comportamento de larvas infestantes de Boophilus microplus em pastagem de Brachiaria decumbens. Ciência Rural, 32(3), 467-472. doi: 10.1590/S0103-847820020003 00016

George, J. E., Pound, J. M., \& Davey, R. B. (2004). Chemical control of ticks on cattle and resistance of these parasites to acaricides. Parasitology, 129(1), 353-366. doi: 10.1017/S0031-182003004682

Hoffmann, R., Serrano, O., Neves, E. M., Thame, A. C. de M., \& Engler, J. J. de C. (1981). Administração da empresa agrícola. São Paulo: Pioneira.

Kasai, N., Labruna, M. B., Pires, A. V., Louvandini, H., Abdalla, A. L., \& Gennari, S. G (2000). Dinâmica populacional de Boophilus microplus (Canestrini, 1887) em bovinos leiteiros mantidos em manejo de pastejo rotativo de capim-elefante. Arquivo Brasileiro de Medicina Veterinária e Zootecnia, 52(5), 453458. doi: 10.1590/S0102-09352000000500008

Lopes, M. A., Lima, A. L. R., Carvalho, F. de M., Reis, R. P., Santos, I. C., \& Saraiva, F. H. (2004). Controle gerencial e estudo da rentabilidade de sistemas de produção de leite na região de Lavras (MG). Ciência e Agrotecnologia, 28(4), 883-892. doi: 10.1590/ S1413-70542004000400022

Lopes, M. A., \& Santos, G. dos. (2007). Custo da implantação da rastreabilidade em bovinocultura utilizando os diferentes métodos de identificação permitidos pelo SISBOV. Ciência Animal Brasileira, 8(4), 657-664. 
Lopes, M. A., Silva, M. das D., Demeu, A. A., Gomide, D. R., \& Bruhn, F. R. P. (2013). Custo da implantação e utilização de dois métodos de identificação de bovinos leiteiros. Revista Ceres, 60(6), 757-764. doi: 10.1590/S0034-737X2013000600003

Lopes, M. A., Vieira, J. A., Lima, F. H. S. de, Demeu, F. A., Bruhn, F. R. P., Pereira, A.,... Casas, P. S. (2018). Technical and economic efficiency of bovine weighing methods. Semina: Ciências Agrárias, 39(3), 1167-1180. doi: 10.5433/1679-0359.2018v3 9 n3p1167

Melo, V. S. P., Passos, L. M. F., Facury, E. J., Saturnino, H. M., \& Ribeiro, M. F. B. (2001). Natural infection on calves by Anaplasma marginale in dairy herds of the Metalurgica region, Minas Gerais. Pesquisa Veterinária Brasileira, 21(4), 46-150. doi: 10.1590/ S0100-736X2001000400004

Néri, N., Toledo, L., Arcaro, I., \& Ambrósio, L. (2016). Estimulação tátil em novilhas leiteiras: efeitos no comportamento e na produção de leite após o parto. Boletim de Indústria Animal, 73(3), 171-179. doi: 10.17523/bia.v73n3p171

Peters, M. D. P., Barbosa, I. D. S., Machado, L. C. P., Machado, A. A., \& Pereira, L. M. R. (2010). Manejo aversivo em bovinos leiteiros e efeitos no bem-estar, comportamento e aspectos produtivos. Archivos de Zootecnia, 59(227), 435-442.

Piper, E. K., Jackson, L. A., Bielefeldt-Ohmann, H., Gondro, C., Lew-Taboe, A. E., \& Jonsson, N. N. (2010). Tick susceptible Bos taurus cattle display an increased cellular response at the site of larval Rhipicephalus (Boophilus) microplus attachment, compared with tick-resistance Bos indicus cattle. Internacional Journal for Parasitology, 40(4), 431441. doi: 10.1016/j.ijpara.2009.09.009
Rocha, C. M. B. M., Oliveira, P. R., Leite, R. C., Cardoso, D. L., Calie, S. B., \& Furlong, J. (2006). Percepção dos produtores de leite do município de Passos, MG, sobre o carrapato Boophilus microplus (Acari: Ixodidae), 2001. Ciência Rural, 36(4), 1235-1242. doi: 10.1590/S0103-84782006000400029

Santos, J. C. B. S., Furlong, J., \& Daemon, E. (2000). Controle do carrapato Boophilus microplus (Acari: Ixodidae) em sistemas de produção de leite da microrregião fisiográfica fluminense do Grande Rio - Rio de Janeiro. Ciência Rural, 30(2), 305-311. doi: 10.1590/S0103-84782000000200018

Silva, M. C. L., Neves, R., \& Linhares, G. F. C. (2000). Avaliação in vitro da eficácia do clorfenvinfós e da cialotrina sobre o Boophilus microplus, colhidos em bovinos da bacia leiteira da microrregião da GoiâniaGoiás. Ciência Animal Brasileira, 1(2), 143-148.

Spagnol, F. H., Paranhos, E. B., \& Albuquerque, G. R. (2010). Avaliação in vitro da ação sobre o Rhipicephalus (Boophilus) microplus Canestrini, 1887(Acari:Ixodidae) de bovinos leiteiros no município de Itamaraju, Bahia, Brasil. Ciência Animal Brasileira, 11(3), 731-736.

Sutherst, R. W., \& Comins, H. N. (1979). The management of acaricide resistance in the cattle tick, Boophilus microplus (Canestrini) (Acari: Ixodidae), in Australia. Bulletin of Entomological Research, 69(3), 519-537. doi: 10.1017/S0007485300019015 
